\title{
American
}

Journal of

International

Law

January 1990

Vol. 84 No. 1

Published by

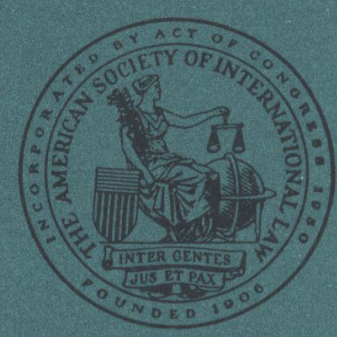

American Society of International Law 


\section{PATRONS OF THE SOCIETY}

Arthur H. Dean (deceased)

Herman Phleger (deceased)

Genevieve E. Tillar (deceased)

W. ROBERT MORGAN

BRUNSON MACCHESNEY (deceased)

Alona E. Evans (deceased)

JOHN N. HAZARD

JOHN R. STEVENSON

Arthur R. Albrecht

ALWYN V. FREEMAN (deceased)

EDWARD DUMBaUld

KEITH HIGHET

STEPHEN M. SchWEBEL

William D. Rogers
SEymour J. Rubin

John Lawrence Hargrove

Frank A. BAUMAN

RICHARD W. EDWARDS, JR.

Hussam Almeshal

MrS. RichaRd BAXTER

ENRIQUE P. SYQUia

Rita E. Hauser

Howard M. HoltzmanN

ArTHur W. Rovine

OSCAR SCHACHTER

BASIL S. YANAKAKIS

GERALD AKSEN

\section{In Memoriam}

\section{Dr. JAMES Brown SCOTT \\ HENRY C. MORRIS}

ArThur K. KUHN

Alexander Freeman

\section{STANLEy P. SMITH}

\section{PATRONAGE, GIFTS AND BEQUESTS}

Upon donation to the Society of $\$ 5,000$ or more by gift or bequest, any member of the Society or individual eligible for membership may be elected a Patron of the Society. Upon donation of at least $\$ 5,000$ in the name of a deceased person, such person may be elected a Patron posthumously.

Gifts and bequests may be made in the name of the American Society of International Law, Washington, D.C. Such contributions are deductible from federal returns for income, estate and gift tax purposes. The Society is incorporated by Act of Congress approved September 20, 1950 (64 Stat. 869).

\section{MANLEY O. HUDSON MEDAL}

The American Society of International Law bestows from time to time without regard to nationality a gold medal to commemorate the life work of Manley O. Hudson. Such awards are made for preeminent scholarship and achievement in international law and in the promotion of the establishment and maintenance of international relations on the basis of law and justice. Medals have been awarded to Manley O. Hudson (1956), Lord McNair (1959), Philip C. Jessup (1964), Charles De Visscher (1966), Paul Guggenheim (1970), Myres S. McDougal (1976), Eduardo Jiménez de Aréchaga (1978), Richard Reeve Baxter (1981), Oscar Schachter (1981), Hardy Cross Dillard (1982), Suzanne Bastid (1984), Marjorie M. Whiteman (1985) and Leo Gross (1986).

The AMERICAN JOURNAL OF INTERNATIONAL LAW (ISSN 0002-9300) is published quarterly, in January, April, July and October, and is supplied to all members of the American Society of International Law. Annual subscription rate to nonmembers is $\$ 75.00$, plus $\$ 5.00$ postage outside U.S.A. Available back numbers of AJIL will be supplied at $\$ 25.00$ each.

EDITORIAL. OfFICE:

New York UnIVERSITY SChOOL OF LaW 40 WASHINGTON SQUARE SOUTH NEW YORK, N.Y. 10012
BUSINESS OFFICE:

2223 Massachusetts Avenue, N.W. WASHINGTON, D.C. 20008-2864

Second-class postage paid at Washington, D.C. and at additional mailing office. POSTMASTER: If undeliverable, send notice on Form 3579 to the American Journal of International Law, 2223 Massachusetts Ave., N.W., Washington, D.C. 20008-2864.

Copyright (c) 1990 by The American Society of International Law Printed by Lancaster Press, Lancaster, Pa. 17603 


\section{AMERICAN JOURNAL \\ OF \\ INTERNATIONAL LAW}

VOL. 84

January 1990

NO. 1

CONTENTS

PAGE

Has International Law Failed the Elephant?

Michael J. Glennon

Prolonged Military Occupation: The Israeli-Occupied Territories

Since 1967

Adam Roberts

The Nature of the Iran-United States Claims Tribunal and the

Evolving Structure of International Dispute Resolution

David D. Caron

The Canada-France Maritime Boundary Case: Drawing a Line around

St. Pierre and Miquelon Ted L. McDorman

Agora: What Obligation Does Our Generation Owe to the Next? An Approach to Global Environmental Responsibility

Do We Owe a Duty to Future Generations to Preserve the Global Environment? Anthony D'Amato

Our Rights and Obligations to Future Generations for the Environment

Edith Brown Weiss

Our Responsibility to Future Generations

Lothar Gündling

207

Editorial Comments

Enhancing the Effectiveness of the Prohibition of Discrimination against Women

Theodor Meron

Admission of "Palestine" as a Member of a Specialized Agency and Withholding the Payment of Assessments in Response

Frederic L. Kirgis, Jr.

Correspondence

From Judge Manfred Lachs, Ambassador Octavio Errázuriz, Professor

Frederic L. Kirgis, Jr., and Howard N. Meyer

Contemporary Practice of the United States Relating to

International Law

Marian Nash Leich

International Decisions

Peter D. Trooboff

Current Developments

Wilsonianism Redux: Inadvertent Publication of Secret

Protocol, Hungarian-East German Agreement on

Visa Requirements

T. M. F. 281

The Council for Mutual Economic Assistance and the European Community

Book Reviews and Notes

Edited by Detlev Vagts

Damrosch, Lori Fisler (ed.). The International Court of Justice at a Crossroads (Rudolf Bernhardt) 
Horn, Frank. Reservations and Interpretative Declarations to Multilateral Treaties (John King Gamble, Jr.)

Bailey, Sydney D. The Procedure of the UN Security Council $(2 \mathrm{~d}$ ed.) (Frederic L. Kirgis, Jr.)

Soviet Year-Book of International Law, 1987 (John N. Hazard)

Dinstein, Yoram. War, Aggression and Self-Defence (John H. McNeill)

Le Procès de Nuremberg: Conséquences et actualisation (Benjamin B. Ferencz)

Alston, P., and K. Tomaševski (eds.). The Right to Food (Penelope B. Rundle)

Tomaševski, Katarina (ed.). The Right to Food: Guide Through Applicable International Law (Penelope B. Rundle)

Halberstam, Malvina, and Elizabeth F. Defeis. Women's Legal Rights: International Covenants an Alternative to ERA? (Rita E. Hauser)

Martin, David A. (ed.). The New Asylum Seekers: Refugee Law in the 1980s. The Ninth Sokol Colloquium on International Law (Peter $\mathbf{H}$. Schuck)

Bojarc, Jury R. Voprosy grazhdanstva v mezhdunarodnom prave (Paul Weis)

Weil, Prosper. Perspectives du droit de la délimitation maritime (Natalino Ronzitti)

Leanza, Umberto, and Luigi Sico. Mediterranean Continental Shelf: Delimitations and Regimes. International and National Legal Sources (R. R. Churchill)

Pak, Chi Young. The Korean Straits (Luke T. Lee)

Kiss, Alexandre. Droit international de l'environnement (Edith Brown Weiss)

Makarczyk, Jerzy. Principles of a New International Economic Order: A Study of International Law in the Making (Nicholas R. Doman)

Trade Policies for a Better Future: The 'Leutwiler Report', the GATT and the Uruguay Round (Peter D. Ehrenhaft)

Petersmann, Ernst-Ulrich, and Meinhard Hilf (eds.). The New GATT Round of Multilateral Trade Negotiations: Legal and Economic Problems (Daniel K. Tarullo)

Rodman, Kenneth A. Sanctity Versus Sovereignty: The United States and the Nationalization of Natural Resource Investments (Rudolf Dolzer)

Legal Guide on Drawing Up International Contracts for the Construction of Industrial Works (Matthew S. Perlman)

Santos Belandro, Rubén B. Arbitraje Comercial Internacional: Tendencias y Perspectivas (Horacio A. Grigera Naón)

Slomanson, William R. International Business Bibliography (C. Anthony Valladolid)

Lillich, Richard B. The Valuation of Nationalized Property in International Law. Volume IV (Henry T. C. Hu)

Briefer Notices: Oda, 352; Malintoppi, 353.

Collected Essays: Le droit international à l'heure de sa codification, études en l'honneur de Roberto Ago, Volumes I-IV, 353.

Books Received

International Legal Materials. Contents, Vol. XXVIII, No. 5

(September 1989) and No. 6 (November 1989) 


\title{
BOARD OF EDITORS
}

\author{
Editor in Chief
}

Thomas M. Franck

New York University School of Law

GEORGE H. AldRICH

The Hague, Netherlands

RICHARD B. BILDER

University of Wisconsin Law School

Jonathan I. CHARNeY

Vanderbilt University School of Law

AnTHONy D'Amato

Northwestern University

School of Law

Richard A. FAlK

Princeton University

TOM J. FARER

University of New Mexico School of Law

Michael J. Glennon

University of California, Davis School of Law

EDWARD GORDON

Albany Law School, Union University

KeITh HigheT

The Fletcher School of Law and Diplomacy, Tufts University

JOHN H. JACKSON

University of Michigan Law School

HAROLD K. JACOBSON

University of Michigan
FREDERIC L. KIRGIS, JR.

Washington and Lee University School of Law

Cynthia C. Lichtenstein Boston College Law School

RichaRd B. LiLlich University of Virginia Law School

ANDREAS F. LOWENFELD New York University School of Law

THEODOR MERON New York University School of Law

BERNARD H. OXMAN University of Miami School of Law

W. Michael ReismaN Yale Law School

William D. RoGers Washington, D.C.

Peter D. Trooboff Washington, D.C.

Detlev F. Vagts Harvard Law School

EDITH BROWN WEISS Georgetown University Law Center

BURNS H. WESTON University of Iowa College of Law

John Lawrence Hargrove, Ex Officio Washington, D.C.

Honorary Editors

Herbert W. BRIGGS (1900-1990) Cornell University

\section{LEO GROSS}

The Fletcher School of Law and Diplomacy, Tufts University

JOHN N. HAZARD

Columbia University School of Law

LOUIS HENKIN

Columbia University School of Law

MonRoe LeIGH

Washington, D.C.

OLIVER J. LISSITZYN

Columbia University School of Law

Myres S. McDougal

Yale Law School
Covey T. Oliver
University of Pennsylvania Law School

Stefan A. Riesenfeld University of California, Berkeley School of Law

SEYMOUR J. RUBiN Washington College of Law, American University

OScar SCHachter Columbia University School of Law

LOUIS B. SOHN University of Georgia Law School

ERIC STEIN

University of Michigan Law School

RichaRd YounG

Van Hornesville, N.Y.

\section{Associate Editor \\ AnNa Ascher \\ Editorial Assistant \\ Virginia CoRneTt \\ Assistant Editor Emerita \\ ELEANOR H. FINCH}




\section{The American Journal of International Law}

The views expressed in the articles, editorial comments, book reviews and notes, and other contributions which appear in AJIL are those of the individual authors and are not to be taken as representing the views of the Board of Editors or the American Society of International Law.

Manuscripts in triplicate may be sent to the Editor in Chief of AJIL, Professor Thomas M. Franck, New York University School of Law, 40 Washington Square South, New York, N.Y. 10012. All footnotes should be typed double space at the end of the manuscript. Please do not make multiple submissions to other journals. Persons making submissions are invited to indicate whether their manuscript is available on an IBM-PC diskette. AJIL uses WordPerfect 4.2. Subscriptions, orders for back numbers, correspondence with reference to AJIL and books for review should be sent to the AMERICAN JOURNAL OF INTERNATIONAL LAw (ISSN 0002-9300), 2223 Massachusetts Avenue, N.W., Washington, D.C. 20008-2864.

Authorization to photocopy items for internal or personal use, or the internal or personal use of specific clients, is granted by the American Society of International Law for users registered with the Copyright Clearance Center (CCC) Transactional Reporting Service, provided that the base fee of $\$ 5.00$ per copy, plus $25 \$$ per page is paid directly to CCC, 27 Congress St., Salem, MA 01970. For those organizations that have been granted a photocopy license by CCC, a separate system of payment has been arranged. The fee code for users of the Transactional Reporting Service is: $0002-9300 / 90 \$ 5.00+.25$.

\section{The American Society of International Law}

The American Society of International Law was organized in 1906 "to foster the study of international law and to promote the establishment and maintenance of international relations on the basis of law and justice."

Society membership is open to all persons of whatever nationality and profession who are interested in its objectives. Dues are: regular, $\$ 80$; special category, $\$ 40$ for persons not resident in a member country of the Organisation for Economic Co-operation and Development; intermediate, $\$ 35$; student, $\$ 20$. Membership application form is printed at the back of each issue of AJIL.

OFFICERS OF THE SOCIETY, 1989-1990

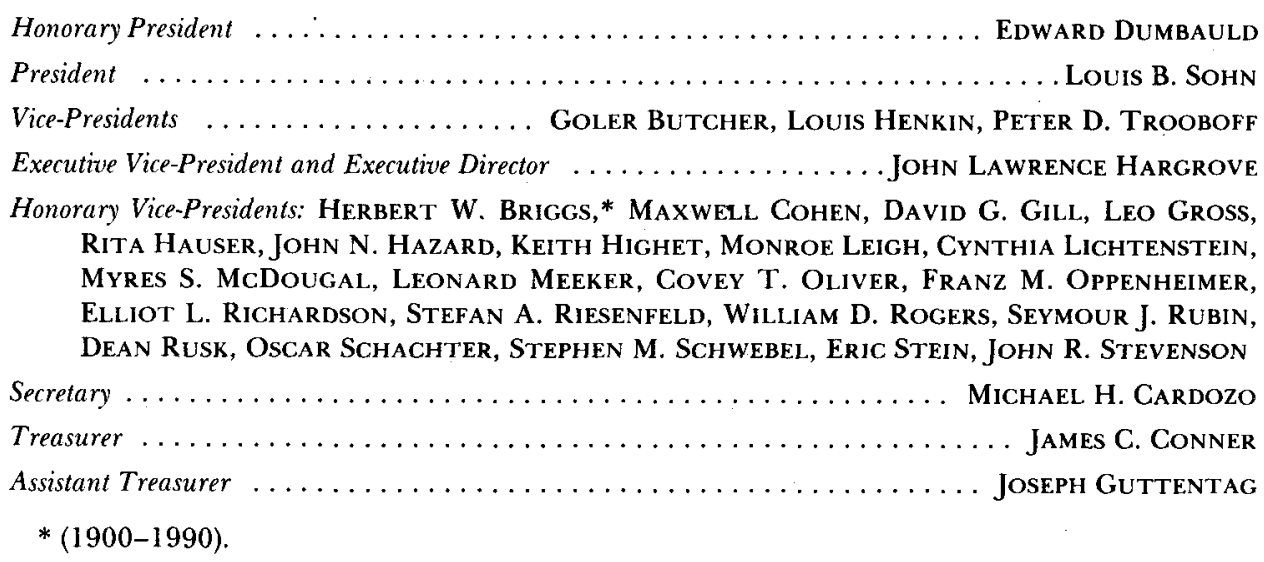

